\title{
1948 to 1951: The racial politics of humanitarianism and return in Palestine
}

OÑati SoCio-Legal Series, Volume 10, Issue 6 (2020), 1242-1269: Governing the Political: LAW AND THE POLITICS OF RESISTANCE

DOI LINK: HTTPS://DOI.ORG/10.35295/OSLS.IISL/0000-0000-0000-1128

RECEIVED 03 SEPTEMBER 2018, ACCEPTED 14 NOVEMBER 2018

\author{
SHAIRA VADASARIA* (iD)
}

\section{Abstract}

The unresolved question of Palestinian displacement raises important considerations in a settler colonial era of reparations. One line of inquiry that remains relevant for thinking about the future of redress to Palestinian displacement is the following: How did an Indigenous Palestinian society with historical ties to land come to be governed as refugees external to the land? Examining a set of progress reports issued by Count Folke Bernadotte - the first UN appointed Mediator on Palestine - this paper considers how a land-based reparative justice question became folded into a humanitarian structure, which has now stretched the course of seven decades. Centering the struggle for return as a site of ontological contestation, I consider how we might read these key decisions made between 1948-1951 around redress and the emergence of humanitarian governance as part of, and within a wider genealogy of race and settler colonialism in Palestine.

\section{Key words}

Race; return; humanitarianism; redress; Palestine

\section{Resumen}

La cuestión irresoluta del desplazamiento palestino plantea importantes consideraciones en una era de reparaciones del colonialismo de asentamiento. Una de

\footnotetext{
I thank Carmela Murdocca and Laura Kwak for their insightful comments on this paper and involvement in organizing the workshop Governing the Political: Law and the Politics of Resistance hosted by the Oñati International Institute for the Sociology of Law as well as the editor of IISL, Leire Kortabarria for her support in putting together this special issue and the blind reviewers for their comments. I also thank the Global and International Studies Program (BGInS) at Carleton University for inviting me to present an earlier draft of this paper. Additionally, I wish to thank a number of people that offered critical insights and generous comments on earlier drafts of this paper including Andrea Cassatella, Sherene Seikaly, Tamara Essayad, Nayrouz Abu Hatoum, Sobhi Samour, and Rahaf Salahat.

* Shaira Vadasaria is a Lecturer in the School of Social and Political Science at the University of Edinburgh. 15a George Square, Edinburgh, EH8 9LD. E-mail address: svadasar@exseed.ed.ac.uk.
} 
las líneas de investigación que continúa siendo relevante para reflexionar sobre el futuro de la resolución del desplazamiento palestino es la siguiente: ¿Cómo llegó la sociedad indígena palestina, con lazos históricos con la tierra, a ser considerada y gobernada como sociedad refugiada ajena a la tierra? Haciendo un repaso de unos informes de progreso escritos por el conde Folke Bernadotte, primer Mediador para Palestina de las Naciones Unidas, este artículo reflexiona sobre cómo una cuestión de justicia reparadora basada en la tierra quedó incorporada en una estructura humanitaria, la cual tiene ya siete décadas de existencia. Centrando la lucha por el retorno como sitio de contestación ontológica, planteo cómo se pueden leer esas decisiones clave tomadas entre 1948 y 1951 acerca de la reparación y la emergencia de la gobernanza humanitaria como parte de, y dentro de una genealogía más amplia de raza y colonialismo de asentamiento en Palestina.

\section{Palabras clave}

Raza; compensaciones; retorno; humanitarismo; Palestina 


\section{Table of contents}

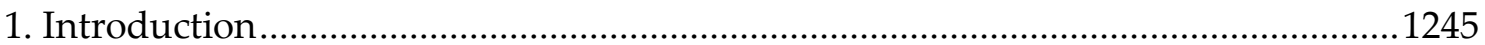

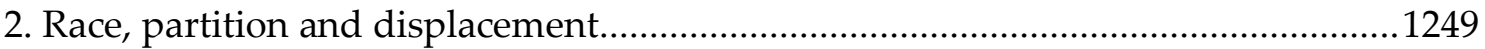

3. Count Folke Bernadotte and the blueprint for return ..........................................1254

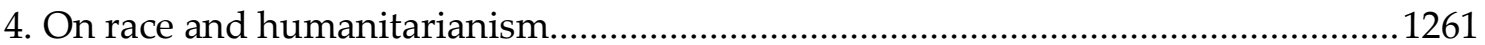

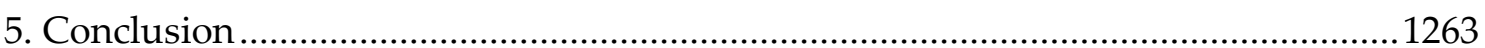

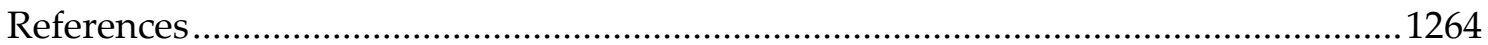

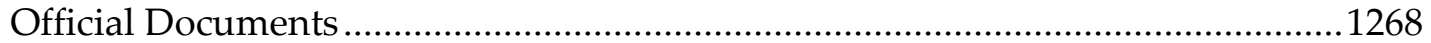


In concluding this part of my report, I must emphasize again the desperate urgency of this problem. This choice is between saving the lives of many thousands of people now or permitting them to die [...]. I believe that for the international community to accept its share of responsibility for the refugees of Palestine is one of the minimum conditions for the success of its efforts to bring peace to that land.

Count Folk Bernadotte, Progress Report of the United Nations Mediator on Palestine (A/648), 16 September 1948 [emphasis added]

The tent will be upsetting on the first night... and then in the first year, and then it will become friendly like a member of the family, but don't fall in love with it like we did. (...). Listen to me, I have 63 years more experience in this 'job' than you: Don't take pictures with Goodwill Ambassadors, don't complain to them about how hot it is or about the pebbles you found in bread. Tell them that your problem is not emotional, and that an Angelina Jolie visit will not solve it. And be careful not to ask for a better tent, as there is no tent better than another.

Ibrahim Jaber Ibrahim 2011/2012, A Letter from a Palestinian Refugee to a Syrian Refugee

\section{Introduction}

How might we think about the history of redress and humanitarianism in the early years of Palestinian displacement as tied to a broader genealogy of race and settler colonialism in Palestine? The territorial realization of the Israeli state produced a new category of stateless people: Palestinian refugees. Those expelled from their villages, homes and land during the onset of the Nakba constitute one of the largest and longest standing protracted refugee communities worldwide today. ${ }^{1}$ On 16 September 1948, Count Folke Bernadotte, the first appointed United Nations Mediator on Palestine concluded his ninety-four-page report with the first epigraph cited above. Upon his observations and broad survey of the conditions on the ground that ensued immediately after 14 May 1948 to early September 1948, Bernadotte lays down a legal blueprint for what would later become adopted as UN General Assembly Resolution 194: The Right of Return (Haq al'Awda). This early gesture of international recognition of the Palestinian right to return takes place within a matter of weeks following Israel's state declaration (Text of Suggestions S/863). As explained in the final remarks of Bernadotte's report, what contours the choice between life and death at this critical historical juncture, is the necessity of a newly displaced Palestinian people to return to their homes and villages upon their desire and immediate opportunity. In his last written observation submitted to the United Nations General Assembly, Bernadotte informs the international community that peace on this land requires return as the primary means of legal redress. The day following the publication of this report, Bernadotte was assassinated in Jerusalem by militants of a Jewish extremist paramilitary organization group known as "Stern Gang" or "Lehi" in its Hebrew name (Osipenko 2016). Speculations suggest that Bernadotte's recommendation for the immediate return of Palestinian refugees was the central reason for his assassination. The very idea of Palestinians returning to their land

\footnotetext{
${ }^{1}$ I refer here to the "onset" of the Nakba as a way to signal to it as an on-going structure of settler colonialism that allows for the continuation of Palestinian dispossession and displacement today. A second phase of mass expulsion took place in 1967, when 300,000 Palestinians were forcibly displaced, more than a third of whom were being uprooted for a second time (Collins 2004). The officially registered Palestinian refugee population today has reached over five million people - two million of whom continue to live in camps in the West Bank and Gaza. See Sayigh 1979, Al-Khalidi 1992, Masalha 1992, Sa'di and Abu-Lughod 2007.
} 
in 1947-1948 and thereafter would threaten the settler colonial project in the making. In fact, it was so categorically undesirable to a newly forming settler state that Palestinian returnees - those that did find their way back in the early years post-expulsion were legally classified as "infiltrators" and became subject to a "shoot to kill" policy (Shalhoub-Kevorkian 2016). ${ }^{2}$ While the idea of Palestinian return was unthinkable to a settler colonial imaginary at this moment, it was not to the 750,000 refugees that were, as Nadia Abu El Haj $(2010,34)$ explains - "experiencing exile for the time in history". Making an analytical claim, she argues that at this very raw moment, it was "inconceivable that, in contrast to all the successful anticolonial independence movements of the past few decades, Palestine would - could - be lost". ${ }^{3}$

Today, seven decades later, the unresolved question of Palestinian displacement raises important considerations in a settler colonial era of reparations. One line of inquiry that remains relevant for future redress to Palestinian displacement includes the following: How did an Indigenous society with historical ties to land come to be governed as refugee subjects external to the land? Put differently, why at this critical historical juncture, did the United Nations prioritize the distribution of humanitarian aid over land repatriation for a newly displaced native Palestinian society? The significance of this inquiry is that this wave of Palestinian displacement took place at the onset of a postworld war II era - a time of consolidated nation-state building and the emergence of citizenship regimes. How ideas about indigeneity and refugeehood came to form at this historical moment has important implications for questions of redress, present and future. To think further about its implication, this paper examines the racial politics of return and humanitarianism in the immediate aftermath of Palestinian displacement during the start of the Nakba. But first, why begin with return?

As Palestinian refugees and non-refugee scholars, artists, legal practitioners and organizers committed to Palestinian self-determination have insisted, Haq al-'Awda - the right to return, remains at the center of the political struggle for a sovereign Palestine. ${ }^{4}$ This is evidenced in the scholarly and cultural works of writers, poets, filmmakers and artists that feature return as a motif that enriches and animates discussions of Palestinian loss and exile and the complicated place of repair and futurity. Literal and more abstract representations of return such as those found in Ghassan Kanafani's Returning to Haifa

\footnotetext{
2 As Nadera Shalhoub-Kevorkian $(2016,171)$ explains, "refugees went from stateless and homeless to being fundamentally illegal overnight". After 1954, the Knesset criminalized the act of returning through the "Prevention of Infiltration (Offences and Jurisdiction) Law 5714, which in effect applied retroactively to punish those that entered as early as 29 November 1947 (during the start of the Nakba - before the state of Israel was declared). As Shalhoub-Kevorkian further points out, this law was also used to further expel Palestinians who had never left Israel but lacked documentation to show otherwise. See ShalhoubKevorkian 2016. Also see Robinson 2013.

3 To provide context to this passage, Abu El-Haj makes this argument as a response to David Goldberg's (2008) commentary on the refusal of recognition between both Palestinian and Israeli leaders. Noting the asymmetry between these forms of refusal at the level of rhetoric versus acts, she stresses how the recognition of Israel by Palestinian refugees in the early years of its formation would have meant "ratifying their own dispossession" (35). See Abu El Haj 2010.

4 See the robust archive of publications produced by legal experts and field researchers with Badil Resource Center for Palestinian Residency and Refugee Rights (2011). This leading civil society organization on Palestinian refugee advocacy work in the Occupied West Bank (Bethlehem) has done extraordinary legal advocacy work and training as well as campaigning and publishing for the past twenty years.
} 
(2000) or Larissa Sansour's film, In the Future, They Ate From the Finest Porcelain (2016) invite an affectively textured and nuanced set of narratives about return and its afterlife. ${ }^{5}$ Despite variations in what imaginings of what return will look like, including more recent debates about returning to a non-state solution (see, for instance, Azeb quoted in The Funambulist 2014, Erakat 2019, Fahoum 2019), the project of return is very much alive, dynamic in iteration and engendered across simultaneous temporal registers (Sayigh 1979, Abourahme 2011, Richter-Devroe 2013, Allan 2014, Salih 2016, Vadasaria 2018). Return signals to a time of historical loss and a time attenuated to a future Palestine. Return lives in a political imagining of a time and place that has not yet arrived or arrived fully yet, though indeed ever present at the level of everyday consciousness and aesthetics, which is especially true inside the corridors and alleyways of Palestinian refugee camps today. Return need not only be understood as a claim to historical memory of past injustice or a reparative justice principle oriented towards the future, though it is often both of these things as well. Instead, I am suggesting here that when we pay attention to how return comes to be represented, remembered, enacted and represented across scholarly, cultural and aesthetic works as well as everyday invocations including larger scale popular protests such as what we have seen happening with the "March of Return in Gaza," we are pointed towards an understanding of return as a locus point for broader claims to justice in Palestine. ${ }^{6}$

\section{FIGURE 1}

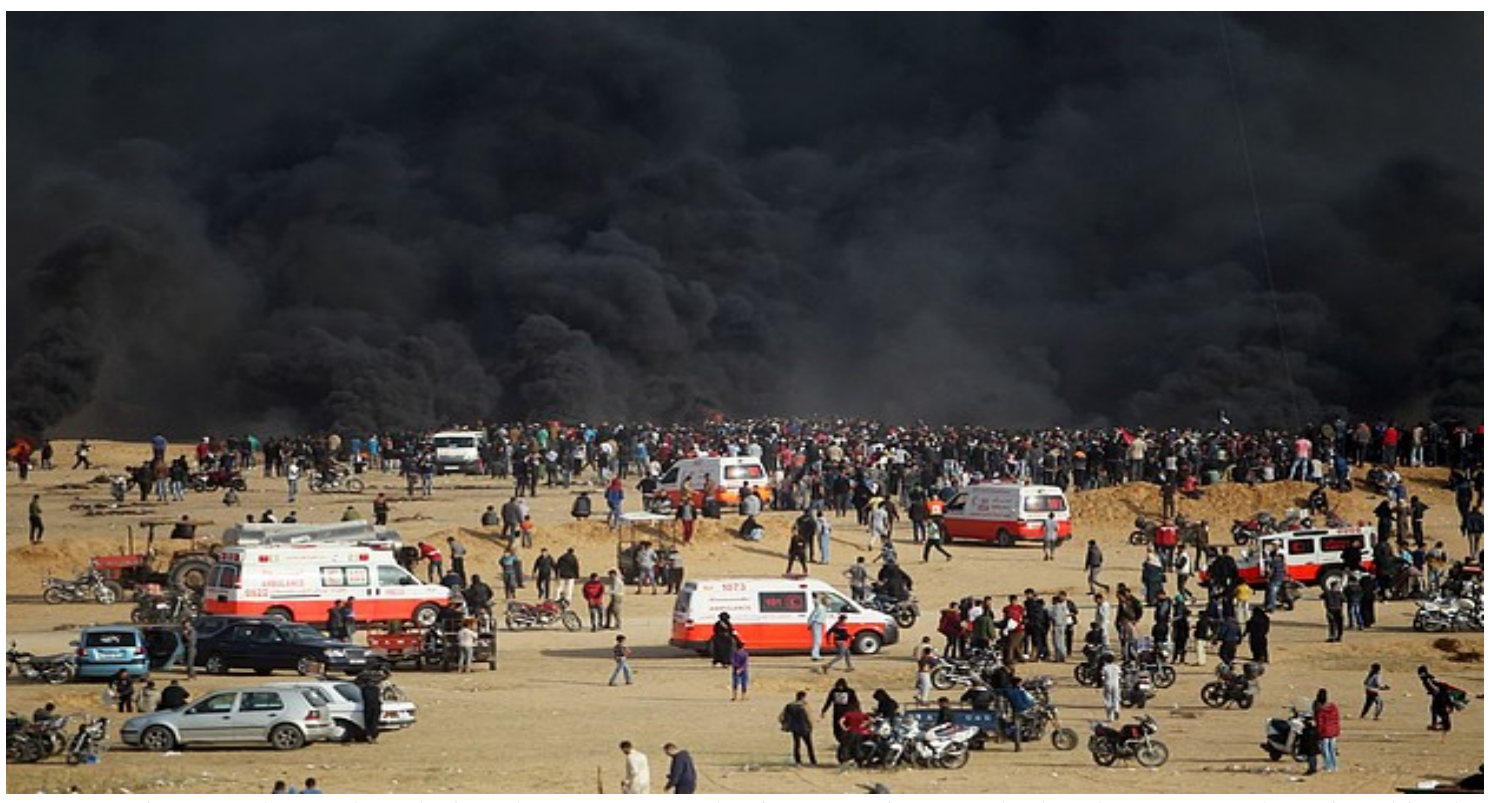

Figure 1 Photo taken during the "Great March of Return" in Gaza (Taken by WHO and reprinted in the United Nations Office for the Coordination of Humanitarian Affairs).

\footnotetext{
${ }^{5}$ While there is no way to contain the scholarly and cultural archive here on return, consider the poetry of Abd al-Karim al-Karmi and Haroun Hashim al Rashid (famously known as the "poet of return") as well as lyrical representations of return in traditional folk sung at social events organized around weddings, martyrdom, and prisoner releases. Additionally, consider the place of return in fida'yeen songs and in more contemporary songs by artists such as Fairouz and the late Rim Banna.

${ }^{6}$ The "March of Return in Gaza" is a popular resistance movement which began on 30 March 2018 at the Gaza/Israel border. These weekly gatherings of hundreds of thousands of unarmed protestors have been met by the Israeli army with lethal force, resulting in the killing of over 200 Palestinians in Gaza (Murphy 2019) and injury of upwards of 29,000 Gazans, over 7,000 of which have been severely wounded by live ammunition (UN Office for the Coordination of Humanitarian Affairs - OCHA - 2019).
} 
To think about return as a locus point for broader claims to justice in Palestine is to think about return as an ontological claim, whereby its very invocation might be understood as a claim to humanity despite the repeated historical denial of Palestinian personhood over the past century. As Edward Said potently proclaimed in After the Last Sky: Palestinian Lives, "[h]istorically, we have been regarded as a population that is essentially disposable" (Said 1986, 130). Yet, against this racialized imaginary, the persistence of return at the level of form (i.e. sites of representation and practice) and iteration, as we've seen enunciated and enacted by Palestinian refugees throughout the past seven decades, compels us to understand claims to return not only as a means for legal redress or a claim bound to the epistemological regime of human rights discourse, but as the very terrain that opens to reconfigurations of the human. To think about the claim to return as a radical reclamation of the human, which I am suggesting here, is to approach return as a kind of decolonial grammar of world-making. In the specific context of Palestine, claims to return can be thought of as a refusal of the confluences of global and settler colonial power that have caused, what Noura Erakat's work powerfully explains, a kind of 'juridical erasure' of Palestinians over the past century (Erakat 2019). To approach return as a mode of refusal is to also think about it as a decolonial order that breaks free from existing terms of reference for justice in Palestine. As put forward in the scholarship of Black and Indigenous thought, this political commitment to refusal is one that goes against the very grain of recognition (Campt 2017, Ferreira da Silva 2018, Hartman 2018) and instead invites us to understand and indeed rethink sovereignty from singular to plural tense (Simpson 2014, Coulthard 2014). It is within this wider reckoning that there is also the possibility to understand return as a claim to, and political imagining of sovereignty beyond the modern nation-state; the possibility for a kind futurity already embodied and practiced in a time and place of extraterritoriality. In the context of Palestinian refugees in camps today, this lived life of refusal, which materializes as an everyday sovereignty from below, brushes up daily against a racial regime constituted at the intersection of Israeli settler colonial nation building and protracted humanitarian governance. Herein lies an entangled story about race and a story about the persistence of lives lived otherwise.

Centering return as a site of ontological contestation, this paper considers how we might read early UN discourse and practices around redress and humanitarianism in the immediate aftermath of Palestinian expulsion as part of a wider genealogy of race and settler colonialism in Palestine. To do so, I turn to a set of progress reports issued between May to September 1948 by the first United Nations Mediator on Palestine, Count Folke Bernadotte. In these documents, we see a precursor and legal blueprint for UN General Assembly Resolution 194, the Right of Return. Despite the Mediator's recommendation for the immediate return of displaced Palestinians as a necessary means for redress, I consider why, at this critical juncture, the UN prioritized the distribution of humanitarian aid over land repatriation for a newly displaced native Palestinian society. I argue that the decisions made by the UN at this historical turning point set in motion, what would later become protracted humanitarian governance in Palestinian refugee camps across the Levant seven decades later. Reading humanitarian governance through an analytic of race, I explain how UN approaches to settler colonial displacement in Palestine at this raw moment obscured the political project of return and Palestinian claims to land as Indigenous subjects in a struggle for sovereignty, not aid. I 
consider how we might read these key decisions made between 1948 and 1951 around redress and the emergence of humanitarianism as part of a longer racial history of settler nation building in Palestine. Approaching race and racialization in this context is not a substitutive reference for ethnicity. Instead, it refers to a constituent of power that organizes the very logic of land dispossession, routine settler violence and settler colonial desire for elimination that manifest through Israeli state policy, architectural planning, infrastructure, and public discourse. Race, operationalized in this context, determines who has rights to land and life in Palestine/Israel and who does not. To think about Palestinian displacement and its humanitarian afterlife as part of a longer genealogy of racial formations in Palestine/Israel signals to ways that Palestinian refugees have been casted outside political orderings of the human under modern colonial life and dropped into, what Achille Mbembe $(2002,40)$ describes as a set of "death-worlds". The claim to return echoes across this racial history and compels us to think about the ontological and epistemological grounds upon which this claim to life and land can be heard. While race is a dynamic and changing category that moves relationally between colonial formations, I invoke it here as an analytic that helps us think further about the broader historical and on-going legal, temporal, social and political discourse that deems Palestinian personhood and recourse to justice illegible.

This article is organized across three parts. In part one I historicize some of the key moments of recognition for future settler state building project in Palestine under British Mandate. Through analyzing the logics that gives rise to UN Resolution 181, the proposed Partition Resolution, I explain how the subsequent creation of Palestinian refugees for the first time in history was already imbued in a global story about race. Part two turns to a set of UN archival records that evidence the forms of settler violence enacted in the months leading up to Israel's state declaration. This section draws on observations and recommendations put in place by Count Folke Bernadotte. Looking closely at his suggestions for remedy and specifically the return of Palestinian refugees between May and September 1948, I explain what his reading of return lent to broader questions around redress for displaced and dispossessed Palestinians at this critical time. In part three, I explain how Bernadotte's final observations gesture to the beginning of a kind of protracted humanitarian structure that has now stretched the course of seven decades. In thinking about the long-term reverberations of humanitarianism under settler colonial life (a meeting point between biopolitical and necropolitical governance), this section highlights the complicated terrain through which the struggle for return is negotiated and lived by Palestinian refugees that remain within these racialized structures today.

\section{Race, partition and displacement}

On 27 November 1947, the UN General Assembly adopted UN Resolution 181, the official legal doctrine which proposed the partition of Palestine and subsequent territorial realization of the Israeli state. If implemented according to its original mark up, the partition plan would have effectively divided Palestine into two democratic states: a Jewish State and an Arab State, with the City of Jerusalem being placed under 
the jurisdiction of a Special International Regime. ${ }^{7}$ This resolution proposed to effectively splinter the land and title in a way that disproportionately favored an incoming settler community at the expense of an Indigenous Palestinian people firmly rooted to the land and in an on-going struggle to secure independence from British Mandate. The concern for many Palestinians at the time was that this resolution flagrantly disregarded the ethnic and demographic composition of the land. Jewish newcomers (settlers and refugees from Europe) who made up roughly one-third of the total population were being offered closer to fifty-six percent of the most fertile land in Palestine including the large cities on the coastal plain. Conversely, Palestinians who made up the majority of the land were expected to settle for approximately forty percent of the inland area. If implemented, the proposed partition plan would institute two other substantive changes: a motion for economic unity between Palestine and Israel and the creation of a United Nations Palestine Commission, which would consist of one representative from five member states (which at the time included Bolivia, Czechoslovakia, Denmark, Panama and Philippines) [see UN General Assembly Resolution A/RES/181 (II)]. This commission would assist in the transfer of administrative authority from British Mandate to the Commission of Provincial Councils of Government of the respective parties (Palestine and Israel). The Commission would also supervise the process of delimiting frontiers between the states; exercise political and military control over the armed militia groups; prepare economic union; distribute assets, maintain administration of public services; protect holy places and importantly, be a liaison between the Mandatory Power and the Jewish Agency for Palestine (UN General Assembly Resolution A/RES/181 (II)).

UN resolution 181 was rejected by both Palestinian leaders and some Zionist leaders alike. Palestinian leadership rejected this offer because at the time, Palestinians made up the overwhelming majority of the population and were being asked to settle for less than forty percent of the land. Zionist leaders were not satisfied with this offer either as they wanted closer to eighty percent of the total land. Challenging the racist character of the Partition Plan, Edward Said asks, "by what moral or political standard are we (Palestinians) expected to lay aside our claims to our national existence, our land, our human rights?" (Said 1979). One explanation afforded was that the uneven redistribution of Palestinian land could be considered compensation for Jewish survivors of the Holocaust in Europe (Pappe 2006). The idea that historical wrongs in the West could be redressed by the usurpation of land in the East reflected the international imbalance of power and imperialist attitudes of the $19^{\text {th }}$ century in a postworld war II era of rights discourse. This racial logic also reflected the deepening of power relations between British administrators and Zionist leaders in the early years of the twentieth century.

In the thirty years leading up to UN Resolution 181, British imperialists in Palestine and Zionist protégés had actively collaborated in planning for the transfer of Palestine from the hands of British Mandate into the creation of a predominantly Jewish state. The presentation of a Jewish state had been considered quite seriously by British colonial powers as early as the nineteenth century. By 2 November 1917, the British Foreign

\footnotetext{
${ }^{7}$ As evidenced in the language invoked around the partition plan, the Arab state is not specified here as a Palestinian state, which signals to the erasure of Palestinians as national subjects.
} 
Secretary Arthur James Lord Balfour welcomed the idea of establishing Palestine as a national homeland for Jewish people. ${ }^{8}$ As described in what is now famously known as the "Balfour Declaration," Balfour declares the following:

His Majesty's Government view with favour the establishment in Palestine of a national home for the Jewish people, and will use their best endeavours to facilitate the achievement of this object, it being clearly understood that nothing shall be done which may prejudice the civil and political rights of existing non-Jewish communities in Palestine, or the rights and political status enjoyed by Jews in any other country. (Balfour 1917, quoted in Corbin 2017)

The significance of this brief but weighty document is that it was the first time in history that the British government publicly endorsed a national and territorial based home for Jewish people in Palestine. As Rashid Khalidi points out, the other two notable things about this declaration is that one, the words "Palestinian" and "Arab" do not appear in the text of the Declaration meaning that "they were not described as a people" (Khalidi 2017). Second, the framework of rights described in the declaration are civil and political - not national. This is important because it works to deny the recognition of a Palestinian national sovereignty, which is a key defining character of the rights bearing subject and remains a key defining character to the very question of Palestine today. These three features of the declaration indeed illuminate how sovereignty in Palestine and the struggle for recognition becomes literally written out of existence. While the passing of the Balfour Declaration is often periodized as the official start of Israeli settler colonialism, it should also be noted that historians and legal scholars such as Sherene Seikaly (2015) and Brenna Bhandar (2018) have further complicated this historical narrative and shown how Balfour is certainly not the origin story of capitalist transformation in Palestine and that this settler history needs to be read alongside a longer and wider history of land ownership transformation under Ottoman land codes. Further, their work has pointed to the need to read settler colonialism alongside a longer history that includes the first wave of Zionist immigration into Palestine in 1880s (Shafir 1989). Scholars of Palestine Studies have also troubled the methodological approaches through which this settler colonial narrative is recounted. Rana Barakat (2017) has insisted for instance, that settler colonialism need not be the only scholarly field or historical narrative that best tells this story. Instead, she urges consideration for what closer engagement with Indigenous Studies and a reading of settler colonial studies alongside Indigenous Palestinian narratives of history might help to illustrate both epistemologically and historiographically (Barakat 2017). I highlight the Balfour Declaration here to demonstrate how Britain's promise to transfer administrative capacities to Zionist leadership is a key moment that gives rise to the creation of Palestinian refugees one hundred years later. In Rashid Khalidi's address to the United Nations on the $100^{\text {th }}$ year anniversary of the signing of the Balfour Declaration, he explains, "the Balfour Declaration in effect constituted a declaration of war by the British Empire on the indigenous population of the land it was promising to the Jewish people as a National Home (...). Zionism was both a nascent national movement and a colonial enterprise in search of a metropolitan sponsor" (Khalidi 2017). In short, this moment is

\footnotetext{
8 The Balfour Declaration refers to a letter written on 2 November 1917 by British Foreign Secretary Arthur James Balfour to Lord Rothschild. In this letter, Balfour agrees to the terms outlined in a Cabinet meeting on 31 October 1917 (see Corbin 2017). The original document is housed at the British National Library.
} 
one key moment in a wider local and regional history that sets up the terrain for an international imagining of partition in Palestine, whereby the sovereignty of its Indigenous inhabitants is already discursively absent.

By the mid 1930's, British Mandate authorities had aided the Zionist movement in carving out a relatively small space for the future state of Jewish settlers, enabling Zionism's abstract vision of an exclusive Jewish homeland to slowly take root. By the early 1940's, David Ben-Gurion and his fellow planners of the Zionist settler colonial project were well beyond imagining the formation of a purely Jewish state. By this time, Zionist leadership had mapped out their vision for Palestine, demanding the entire land of Palestine excluding the West Bank (Pappe 2006). Britain responded to such demands by suggesting the creation of a bi-national state, a solution rejected by the Zionist leaders and viewed as unfavorable by the Palestinians leaders at the time. Britain effectively withdrew all together and ultimately transferred the deciding powers into the hands of the United Nations. ${ }^{9}$ As archived in the Official Records of the Second Session of the General Assembly (1947), UK Representatives addressing the Special Committee on Palestine asserted the following:

We have tried for years to solve the problem of Palestine. Having failed so far, we now bring it to the United Nations, in the hope that it can succeed where we have not. If the United Nations can find a just solution which will be accepted by both parties, it could hardly be expected that we should not welcome such a solution. All we say - and I made this reservation the other day - is that we should not have the sole responsibility for enforcing a solution which is not accepted by both parties and which we cannot reconcile with our conscience. (UN Special Committee on Palestine, A/364)

What this statement elides is the economic interests that Britain had in Zionist leader's promise to fulfil their imperialist ventures. The British government effectively tasks the newly established United Nations the responsibility of crafting a partition plan between Palestine and Israel, upon recommendation by the UN Special Committee on Palestine (UNSCOP) - a position that later gets replaced by the creation of the Mediator appointment. Notably, the crafting of this partition plan was heavily influenced by the United States and the Soviet Union, both of whom were dominant powers in support of the growing Zionist movement. The United Nations General Assembly voted 33 to 13 in favour of the Partition Plan, with ten abstentions. The transfer of administrative capacities from British imperial power to this newly formed international body and consequently into the hands of Zionist leaders (via international recognition of the partition of Palestine) disregarded the devastating impact this would have on the native population of Palestine, who at the time made up the overwhelming majority of the population. What ensued from the passing of this partition plan was a Zionist paramilitary led ethnic cleansing process which, by 1949, resulted in the uprooting of close to eighty percent of the existing Arab society, effectivity creating a new society of refugees (Khalidi 2020).

The transfer of administrative power from British Mandate into the hands of the newly established United Nations was the beginning of a series of rapid shifts in decision making that would eventually give rise to the Nakba. While it was not the United Nations that carried out these assaults, it was the passing of Resolution 181 and proposed

\footnotetext{
${ }^{9}$ For an empirical record of this discussion, see UN Special Committee on Palestine, A/364 (1947).
} 
Partition Plan that set in motion the transfer of administrative capacities into the hands of leaders of a settler colonial project in the making. In short, UN resolution 181 softened the ground for what would soon become a wide-scale militarized campaign of systematic displacement and massacre. As well documented and historicized, the Nakba ("catastrophe") marks the start of a methodically planned aggressive stage of Israeli settler colonial nation building that resulted in the destruction of 531 Arab villages, the emptying out of 11 urban neighbourhoods and the massacre and forcible displacement of 720, 000-750, 000 Palestinians (Pappe 2006, Sa'di and Abu-Lughod 2007, Abdo and Masalha 2018). Nur Masalha documents that during this phase of ethnic cleansing (194748),

122 Arab localities were expelled at gunpoint by Jewish forces; 270 localities were evacuated under assault by Jewish troops; 38 localities were evacuated out of fear of attack or being caught in the cross fire; 12 localities were evacuated as a result of psychological warfare methods, spreading rumors and whispering campaigns. (Masalha 1992, 45)

Following the implementation of the Israeli army's ethnic cleansing plan, as described above, Zionist armies were insistent in the systemic and total destruction of Palestinian villages in both rural and urban areas, and the expulsion of Palestinians from their homeland. As mapped out in the blueprint for Plan D, the project of Zionism as a pure Jewish state could only be accomplished through the annihilation or forced expulsion of non-Jewish bodies, as well as full occupation and de-Arabization of Palestinian land. Plan D was partially accomplished within six-months and 'cleansed' the coastal and inner plains of Palestine (Pappe 2006). This phase of ethnic cleaning resulted in the creation of a Palestinian refugee population for the first time in history. Immediately following Israel's state declaration, state officials claimed the right to exercise permanent control over the remaining parts of Palestine by arguing that it was essential for state security. These accounts help us consider how the partial emptying of Palestinian land and Palestinian people was essential to Israel's state formation as a settler colonial venture. As Nur Masalha (1992) and Joseph Massad (2006) have detailed at great length, the idea of "population transfer" was central to fulfilling the Zionist myth that declared Palestine as empty land. These historical accounts dispel the myth of "voluntary departure," a narrative that obscures the direct and indirect methods of expulsion directed at Palestinian peoples in 1948 and shortly thereafter. Further, these accounts help us think about the ways that racialized ideas about demographic management underpinned the Israeli state's creation, or what, David Theo Goldberg (2008) has called a quintessential "racial state". When we look closely at the discursive and material practices through which British Mandate powers denied the recognition of a sovereign Palestinian nation while transferring control into the hands of Zionist leaders, we see a kind of ontological negation that casts Palestinians as subjects of racial difference. This inscription of racialization via negation of Palestinian rights to their land as lawful indigenous subjects was then renewed through an aggressive Zionist ethnic cleansing campaign that gave rise to the creation of Palestinian refugees for the first time in history. Through revisiting this history of Palestinian expulsion, I am arguing here that the figure of the Palestinian refugee - from the moment of inception, is already imbued in a story about race. 


\section{Count Folke Bernadotte and the blueprint for return}

On 14 May 1948, the day that Israel officially declared statehood, the United Nations General Assembly adopted resolution 186 (S-2), which effectively replaced the Palestine Commission with the position of a Mediator to resolve, what was now being described by the UN at this time as a conflict between "Arab and Jews". The Mediator's role was two-fold: at the level of mediation, they would ensure the safety and well-being of both parties, find common ground for a just solution to the "Palestine Question" and work to repair the damages and displacement that ensued in the months leading up to Israel's state declaration. Second, the appointed Mediator would report back to the Security Council and the Secretary-General for transmission to members of the United Nations via monthly progress reports (Progress Report of the UN Mediator on Palestine A/648 (1948), 1). Interestingly, the duties enlisted in this position also echo almost verbatim the duties outlined for the UN Palestine Commission, which came into effect upon recommendation in UN Resolution 181 (The Partition Plan). Essentially, the responsibilities of the appointed Mediator would replace the UN Palestine Commission which was put in place to withdraw British Mandate from Palestine. Put another way, as British Mandate began phasing out their administrative role in Palestine, they transferred control into the hands of the newly formed United Nations who put in place the UN Palestine Commission to oversee the transition, which was then replaced by the creation of this new appointment of Mediator. Essentially, the appointed UN Mediator would fulfil the weighty obligations at a critical historical juncture in the history of Palestine/Israel relations. Why was Count Folke Bernadotte entrusted with these obligations and what made him a suitable candidate?

In many ways, Bernadotte was sympathetic to the conditions of both Jewish and Palestinian people at this historical turning point. Prior to Bernadotte's appointment as a UN Mediator, he served as the head of the Swedish Red Cross and played an important role in mediating the release of more than 30, 000 prisoners from German concentration camps at the end of World War II. Three years following this rescue mission, often referred to as the "White Buses Campaign," Bernadotte took up the position of "United Nations Mediator on Palestine" which lasted approximately four months before his assassination on 17 September 1948 by members of the Stern Gang. ${ }^{10}$ Two days before his assassination, he had just presented his progress report to government officials in Lebanon and Syria. After arriving back via Qalandiya airport with a short stop at the YMCA West Jerusalem, where the UN truce headquarters was based, he made his way alongside a UN Caravan towards his scheduled meeting with Israeli authorities in Jerusalem. The details of his travel itinerary were forwarded to the UN Truce Supervision Headquarters in Haifa to ensure safe arrangements. After being stopped in the Qatamon Quarter, Bernadotte's vehicle was approached by three armed men dressed in Israeli army uniforms. Bernadotte and Air Force Colonel Andre Serot (who was accompanying Bernadotte and sitting next to him in the car) were struck down with sniper bullets. The autopsy revealed that Bernadotte was shot six times, including one bullet to the heart. He was pronounced dead upon arrival to the hospital (Stranger 1988).

\footnotetext{
10 "White Buses" was an operation advanced by the Swedish Red Cross and Danish government in 1945 in an effort to rescue Jewish and non-Jewish prisoners from Nazi concentration camps and transport them to Sweden. See Al Jazeera 2014.
} 
What threat did this Swedish mediator pose to the newly established State of Israel? In many ways, his final progress report was a testament to the immediate reverberations of a partition enacted against the will of the existing native population. Insisting that the "time was ripe for a settlement," he indicated that "vital decisions will have to be taken by the General Assembly if a peaceful settlement is to be achieved." (Progress Report of the United Nations Mediator on Palestine A/648). Even more bluntly, he emphasized at the beginning of his final report the following:

It is my understanding, at the time this report is written, that the question of the future of Palestine has not been placed on the agenda of the forthcoming session of the General Assembly. I would be less than frank if I did not express my personal view that it will be a mistake of tragic consequences if, at this critical period in the history of Palestine and in the intensive effort to achieve a peaceful solution, the question were not to be considered and the necessary decisions taken by the General Assembly. (Progress Report of the United Nations Mediator on Palestine, A/648 [1948], 3)

Bernadotte's writing evidences here the sensitivity of time in resolving the question of Palestine. It was clear in this report that he identified this historical moment as a key moment to reverse what ensued in the months leading up to Israel's state declaration and shortly thereafter. In the first written submission to the UN General Assembly, Bernadotte outlines the key issues at stake including the defining of territorial boundaries (in consultation with the boundaries commission), economic unity, future immigration policy, the protection of religious and minority rights, the preservation of Holy Places, religious buildings and sites and of notable significance, recognition of the right of Palestinian refugees to return. During his appointment, some other notable tasks he took on included negotiating a one-month truce between Arab and Israeli armies which lasted between 11 June to 9 July 1948; the ordering of a second truce on 18 July 1948, and based on his observations of existing conditions on the ground, a set of revisions to the UN Partition Plan. This entailed the inclusion of Jerusalem and the Negev to "Arab territory" in exchange for assigning the whole or part of the Western Galilee to "Jewish territory", with consideration of Jaffa undetermined, the establishment of a free port in Haifa and a free airport in Lydda (Progress Report of the United Nations Mediator on Palestine A/648, 34). It should be noted however that his initial redrafting of the partition plan was not viewed favorably by the Palestine Arab Higher Committee. In a letter submitted on their behalf by Abdul Rahman Azaam, the Secretary-General of the League of Arab States, Azaam stated the following impression on Bernadotte's proposal:

The suggestions advanced surprised the Political Committee because they are a reproduction of the basis of the partition plan which led to the present armed dispute, and aim at ensuring to one party all its ambitions while neglecting the aspirations and rights of the Arabs, who are the original owners of the country. (Progress Report of the United Nations Mediator on Palestine A/648, 34)

This response demonstrates the Palestine Arab Higher Committee's scepticism that Bernadotte was taking into consideration the viewpoint and experience of a newly displaced native people, which Bernadotte later accounts for in his other observations. As additionally pointed out by the Palestine Arab Higher Committee, the issue of economic unity was being tabled in favor or Zionist settlers and the simple fact that a settler colonial nation could not economically flourish without the labor and knowledge 
of its native population. As Abdul Rahman Azaam explains, "[i]t is a known fact that the Zionists cannot lead an economic existence independent of the Arabs. Economic unity therefore is intended for safeguarding Zionist interests and the exploitation of the Arabs". ${ }^{11}$ The point being made here is that economic unity was being introduced to further the goals of expanding the settler colonial project in Palestine, not in the service of the countries existing native population. It should also be noted that this very moment, the presence of Israel was still being refused by Palestinian leadership. In the words of the Palestine Arab Higher Committee, "Our position is clear, and has been proclaimed on every occasion. It is never to allow the creation of a Jewish State in Palestine, and to exclude participation" ${ }^{12}$ In refusing the permanence of a settler state in Palestine, this statement reflects the very real concerns that Palestinians and Palestinian leadership had about the fate of their future at this historical moment.

After one month of assuming his role as mediator, Bernadotte presented the president of the UN Security Council a four-page letter regarding his observations and suggestions on the current situation. As with his other written submissions, he begins by reiterating that his "prime objective is to determine on the basis of the fullest exploration, whether there is any possibility of reconciling, by peaceful means, the divergent and conflicting views and positions of the two sides" (Text of Suggestions S/863). While the context of his short report was intended to reflect what Bernadotte observed during the four-week truce, he notes quite clearly here, the necessity of return as a condition for lasting peace. The clarity around his suggestion for return was informed by his acute understanding of the expanding asymmetrical relations of sovereignty on the ground.

As Bernadotte further explains,

The most significant development in the Palestinian scene since last November is the fact that the Jewish State is a living, solidly entrenched and vigorous reality. That it enjoys de jure or de facto recognition from an increasing number of States, two of which are permanent members of the Security Council, is an incidental but arresting permanent fact. The Provincial Government of Israel is today exercising, without restrictions on its authority or power, all the attributes of full sovereignty. The Jewish State was not born in peace as was hoped for in the resolution of 29 November, but rather, like many another States in history, in violence and bloodshed. (Progress Report of the United Nations Mediator on Palestine A/648, 5)

This excerpt highlights the Security Council's recognition of Israeli state sovereignty and the state's violation of the partition plan set forth in Resolution 181. It should be noted that the violence that Bernadotte refers to includes both the outcome of the rise of paramilitary violence led by Zionist groups and hostilities - as he describes - of Palestinian and other Arab armies which took succession for a brief period following the declaration of Israeli statehood. Critiquing the Arab army's refusal to accept "the fact of a Jewish State in Palestine," he identifies their resistance as a "tragic mistake in employing force in Palestine" (Progress Report of the United Nations Mediator on Palestine A/648, 6). At the same time that he condemns their resistance to Israeli sovereignty, he also sympathizes with the Palestine Arab Higher Committee in their

\footnotetext{
${ }^{11}$ See the letter addressed to Bernadotte on 3 July 1948 by the Secretary-General of the League of Arab States contained within the Progress Report of the United Nations Mediator on Palestine A/648.

12 Ibid.
} 
very real fear that Jewish immigration would take up the whole of Palestine and Transjordan and not stay within its defined boundaries. This idea was animated by Zionist demands for unlimited Jewish settlement (Progress Report of the United Nations Mediator on Palestine A/648, 7). Bernadotte's critiques of undefined territorialisation and unlimited Jewish settlement was signalling to the dangers of an expanding settler colonial project in the making. It is in this context that he also repeatedly emphasized in his written records the urgency of return for displaced refugees. He addressed this concern as early as 28 June 1948, in his first report to the Security Council and enunciates here the right of Palestinians to return in the following way:

That recognition be accorded to the right of residents of Palestine, who, because of conditions created by the conflict there have left their normal place of abode, to return to their homes without restriction and to regain possession of their property. (Text of Suggestions $S / 863,4)$

Bernadotte affirms here the right of Palestinians to return to their homes and regain their property while evidencing the political context for the conditions upon which they left and/or were expelled. In doing so, he gestures to a reparation approach that includes both repatriation and restitution in the following way:

It is, however, undeniable that no settlement can be just and complete if recognition is not accorded to the right of the Arab refugee to return to the home from which he has been dislodged by the hazards and strategy of the armed conflict between Arabs and Jews in Palestine (...). The exodus of Palestinian Arabs resulted from panic created by fighting in their communities, by rumours concerning real or alleged acts of terrorism, or expulsion. It would be an offence against the principles of elemental justice if these innocent victims of the conflict were denied the right to return to their homes while Jewish immigrants flow into Palestine, and indeed, at least offer the threat of permanent replacement of the Arab refugees who have been rooted in the land for centuries. (Progress Report of the United Nations Mediator on Palestine, A/648, 26; emphasis added)

Bernadotte's comments above might be read as a gesture of international recognition that sympathized with the Palestinian cause. These passages highlight the forms of settler violence that resulted in the creation of a Palestinian refugee context. In acknowledging the rootedness of Palestinians in Palestine for centuries, he also gestures to their location as Indigenous subjects with historical ties to land. These comments do much to challenge the Israeli settler colonial state's founding mythologies predicated on the idea of "voluntary departure". In fact, he evidences the methods of forced displacement in his report in the following way:

There have been numerous reports from reliable sources of large-scale looting, pillaging and plundering, and of instances of destruction of villages without apparent military necessity. The liability of the Provincial Government of Israel to restore private property to its Arab owners and to indemnify those owners for property wantonly destroyed is clear, irrespective of any indemnities which the Provincial Government may claim from the Arab States.

This documentation is important precisely because, as with other settler colonial state projects, Israel's national narrative relies on a kind of amnesia, and a particular adaptation of the quintessential colonial doctrine of terra nullius. Israel's state claims to sovereignty over territory are predicated upon the renewed disavowal of Palestinian displacement and historical claims to memory through a kind of "necronationalism" 
(Vadasaria 2015) and organized upon the politics of power over death (Mbembe 2003, Makdisi 2010, Shalhoub-Kevorkian 2015a). In recognizing the forms of displacement and dispossession required for the inception of the Israeli state, Bernadotte's declarations lay down an archive that documents what the Israeli state has attempted to systematically erase.

During the remainder of the time that Bernadotte served as mediator for the UN, he kept the issue of Palestinian refugees on the table and discussed it in greater detail in his final report. What is noteworthy in his final writings are the ways that he keeps separate the issue of return and humanitarianism with respect to Palestinian refugees. While he addresses both issues, he describes the rights of Palestinian refugees first and foremost as a political question, and the need for immediate relief as a short-term humanitarian endeavour. Bernadotte's description of the "nature of the problem" (referring to Palestinian refugees) is framed around forced expulsion. This context could not be remedied through humanitarian work alone. Yet, it is interesting that his report concludes with emphasis on the immediate relief of basic needs and the short term planned programme. This decision might reflect Bernadotte's growing hesitation that the situation could be easily resolved, a hesitation that was surely inflected by the Israeli state's vehement rejection of his recommendations in general and on the issue of return specifically. In the annex of his final progress report, is a transcript of correspondence letters (via telegrams) between Bernadotte and the Minister for Foreign Affairs of the Provincial Government of Israel. On 1 August 1948, the Minister for Foreign Affairs replied to Bernadotte's recommendations for the right of Palestinians to return by insisting that the return of Palestinian refugees would be of compromise to the security and political and economic interests of the newly formed state of Israel. Take, for example, the following passages:

We are not unmindful of the plight of the Arabs who, as a result of the present war, find themselves uprooted from their homes and cast adrift. Our own people have suffered too much from similar tribulations for us to be indifferent to their hardships. If nevertheless, we find ourselves unable to agree on their readmission to the Israelcontrolled areas, it is because of over-riding considerations bearing on our immediate security, the outcome of the present war and the stability of the future peace settlement. (Progress Report of the United Nations Mediator on Palestine A/648, 27)

In the reasons cited above, we begin to see a logic of securitization already begin to take root at the level of public discourse. The logic of "national security" becomes a governing logic that continues to rationalize and exonerate Israeli war crimes today. This logic functions to legitimize and normalize the expulsion of Palestinians, an expulsion that had taken effect merely a few months prior to these communications. Examining the ways that Israeli security discourse shifted a refugee crisis into a crisis about setter state security, Shalhoub-Kevorkian (2016) argues that discourse around Palestinian returnees "underpinned a public discourse that reimagined Jewish settlers in historic Palestine as native to the land and Palestinians as wayward foreigners and invaders (ShalhoubKevorkian 2016). The longevity and pervasiveness of this securitizing logic within Israeli discourse is noteworthy. Indeed, what we begin to see form early on in the Israeli foreign affair's response to Bernadotte is a racial discourse formed around securitization and later codified through politico-juridical orders such as the Prevention of Infiltration (Offences and Jurisdiction) Law 5714. 
Continuing on the theme of security and the national rights of Jewish people, the Israeli Foreign minister explains:

... your reference to the return of Arab refugees as being one of the questions under dispute which it is the duty of both parties to try and settle peacefully, appears to us to miss the main point at issue. The root cause of the present conflict - of which the mass flight of Arabs and their consequent suffering are mere corollaries - is the refusal of the Arab League to accept the State of Israel either as a matter of right or as an accomplished fact. (Ibid.)

In this claim, we see a kind of discursive gymnastics that disavows entirely the very processes of expulsion enacted in the making of the Israeli state. The Israeli Foreign minister's refusal for the repatriation of Palestine's Indigenous population and restitution for their displacement leads Bernadotte to emphasize in the last ten pages of his report the urgency for immediate humanitarian urgency. As he declares, "[b]y the middle of July the refugee problem had become grave and it was apparent to me that urgent measures had to be taken for humanitarian reasons" (Progress Report of the United Nations Mediator on Palestine A/648, 47). Bernadotte gestures to the need for the creation of a humanitarian agency to ameliorate the situation. He outlines several key features of Palestinian refugee condition that provide reason for immediate humanitarian assistance which begin with the mere fact that Palestinians were turned into stateless population without protection from any recognized government. While it may seem obvious that officers of a humanitarian agency would pay attention to immediate relief and aid requirements including the most basic rations like water, food, shelter, clothing and protection from the climate, what is noteworthy is that at the time, these considerations for humanitarian aid also included recommendations for repatriation. As Bernadotte summarizes: The immediate solution of the problem appeared to be the return to their homes of those refugees who desired to return. Even though in many localities their homes had been destroyed, and their furniture and assets dispersed, it was obvious that a solution for their difficulties could be more readily found there then elsewhere. (Progress Report of the United Nations Mediator on Palestine A/648, 48; emphasis added)

Bernadotte's conclusions in this report emphasize the importance of return alongside the need for urgent humanitarian care. After Bernadotte's assassination, the UN General Assembly set up two programs to deal with the question of Palestine. The first was a short-term mandated humanitarian relief program (United Nations Relief and Work Agency) and the second program (UN Conciliation Commission for Palestine - UNCCP) was designed to find a long-term political solution. By the late 1950s, the UNCCP was no longer active, meaning that UNRWA became the sole body mandated to provide assistance to Palestinian refugees (Irfan 2020). On 1 May 1950, less than two years following this recommendation, UNRWA began their operations as a kind of temporary aid and shelter program and in response to the newly born crisis of Palestinian refugees. As an international humanitarian agency, its mission was to sustain the survival of Palestinian refugees by providing education, employment, medical care, shelter and basic rations. At the same moment that the UN was initiating these emergency humanitarian interventions, UNRWA (United Nations Relief and Work Agency for Palestine Refugees in the Near East) was securing ninety-nine-year land leases in the West Bank, Gaza, Syria, Lebanon and Jordan. These extended land leases ultimately secured permanent shelter projects (i.e. refugee camps) which indeed, coupled with 
Israeli settler colonial expansion plans, was signalling to the start of a permanently temporary refugee crisis and the creation of a new kind of refugee. While the idea of a "refugee" often signals to a kind of temporary and urgent experience in need of humanitarian care and assistance, the prolongation of the Palestinian refugee context, a context tethered to the arrangement of Israeli settler nation building produces a temporal experience of crisis with no end.

As Ilana Feldman's $(2012,2018)$ work explains, humanitarianism is not a temporary experience in the Palestinian refugee context but has become a marker of "lifeworlds." Departing from both Giorgio Agamben's analysis of "bare life" and Didier Fassin's analysis of humanitarianism via the "politics of life" which theorizes the political calculations used to determine the "specific value and meaning to life," (Fassin 2007), Feldman theorizes protracted humanitarianism in Palestinian refugee life through, what she terms the "politics of the living," the "dynamics of being" - of surviving, claiming and acting within structures of humanitarian governance (Feldman 2012, 2018). Reading the ways that Palestinian refugees live within and respond to the biopolitical field of humanitarianism, her work illuminates the ways that refugees come to negotiate their sense of personhood and agency within it. This framework disrupts the hierarchy of power implicit in dominant critiques of humanitarianism and helps us think about the historical specificity of humanitarian agencies like UNRWA that have come to organize social and economic relations in the camp throughout the past seven decades. Not only does UNRWA distribute aid but for registered Palestinian refugees, it functions as a kind of "de facto quasi-governmental function" through "large-scale healthcare and education programs" which, as Anne Irfan explains, "fulfils more of the administrative function of a state" (Irfan 2020, 29). In addition to providing jobs, education, and formal identification, UNRWA has also made viable the symbolic recognition of Palestinian refugee displacement, which was important for the PLO's (Palestine Liberation Organization) internationalist diplomacy efforts particularly in the 1970s (Irfan 2020). While the relationship between UNRWA and the PLO was historically fraught and ambivalently negotiated, they relied on one another for mutual support in tending to the plight of Palestinian refugees. Understanding the complexity of agencies like UNRWA serves as an important reminder of the complicated humanitarian terrain through which Palestinian refugees have been forced to ambivalently negotiate recourse to justice and international recognition upon.

Bernadotte's commentary in his final address to the international community speak to the urgency and necessity of redressing the question of Palestine so that there would in fact be a future for Palestine. Yet, the necessity of return today continues to haunt the question of Palestine. After seven decades of life lived under conditions of protracted displacement, neither the question of Palestine nor return has been resolved. Lasting peace has not been achieved. Perhaps most significantly, the very question of return has become further and further annexed from official negotiations. ${ }^{13}$ What has appeared

\footnotetext{
${ }^{13}$ During the "Oslo Years" (1993-2000) the question of return became both a pressing and under recognized issues at the negotiation table. At the time of peace negotiations, the PLO Chairman, Yasir Arafat came very close to forgoing the right of return in exchange for a peace agreement with the State of Israel. Yet, what would this have meant for the millions of Palestinian refugees waiting for return? Unlike the attempted peace negotiations that took place during the "Oslo Years," the Camp David Summit was the first official political process that took seriously the question of Palestinian refugees. Amidst these discussions of refugee
} 
instead is a precarious structure of protracted humanitarian governance. While humanitarian agencies like UNRWA do keep alive the symbolic recognition of Palestinians as forcibly displaced subjects in addition to the very real and concrete material forms of subsistence, their terms of recognition suspend the political project of return within a humanitarian state of limbo. Further, as I will discuss next, the discursive field through which humanitarianism operates is already consigned to an epistemological knowledge structure indexed by ideas about race.

\section{On race and humanitarianism}

Humanitarianism, broadly defined might be understood as a "mode of governing that concerns the victims of poverty, homelessness, unemployment, and exile, as well as of disasters, famines, epidemics, and wars - in short, every situation characterized by precariousness" (Fassin 2012, x). Additionally, it stretches across law, discourse and practice and can be understood as an arrangement of legal orders and regulatory conditions (i.e. as codified under humanitarian law), a set of "images of suffering", and a set of practices that ensure the provision of emergency aid and social services (Feldman 2012). As Linda Tabar (2016) argues, humanitarianism is not just an imperative of "saving life". Rather, we should understand humanitarianism as "rooted in a much more ambivalent notion of human agency" constituted at the "intersection of European racial hierarchies and imperial formations" (Tabar 2016, 17). Tabar's reading of humanitarianism complicates humanitarianism's moral imperative to respond to suffering as an apolitical gesture towards good will. The non-Western Other, as she explains, is denied their voice and agency, thereby denying the capacity for "indigenous peoples and non-Western subjects to be fully human or to occupy the same space as the white European self" (Tabar 2016, 19). Within the visual economy of humanitarianism, those deemed in need of saving are represented through a depoliticized and dehistoricized imaging whereby they are represented as "helpless victims" and "consigned to their body". Their corporeality is bound to a "speechless" visuality of "suffering and need" (Rajaram 2002, 253).

Talal Asad's (2015) writing on humanitarianism is also instructive for helping us understand its genealogy as one directly tethered to racial orderings of the human. Asad's genealogical reading of liberal humanitarian reason owes its inheritances to the Enlightenment era whereby we see the emergence of a moral call to compassion and benevolence "intertwined with violence and cruelty, an intertwining that is not merely a coexistence of the two but a mutual dependence of each other" (Asad 2015, 393). Fuelled by Christian moralism which establishes ideas about human difference along a vertical "chain of being," the project of humanism sets in motion a classificatory system for deciding who is considered human and who is not. Predicated on ideas about universality and reason, its moral imperative hinges upon ideas about difference, while operating under the guise of universality. The caution that Asad is raising here, is that doctrines of humanitarianism and human rights for that matter, often reconstitute suffering at the very moment that it works to ameliorate historical and on-going

rights, significantly Israel only acknowledged the needs of Palestinian refugees in the context of "humanitarian grounds" (i.e. family unification) and as "humanitarian subjects". Furthermore, during this negotiation, the Israeli state's consideration of accepting Palestinian refugees into the state borders of Israel was limited to 100,000 refugees. Also see Khalidi 1992. 
wrongs. ${ }^{14}$ The legal and visual field through which humanitarianism operates and suffering becomes legible upon is already indexed by a set of racial ideas that determine what counts as violence and whose violence counts. In the context of refugees - who, as Liisa Malkki $(1996,385)$ explains, is not an already constituted and self-delimiting category of people but a "constellation of sociopolitical and cultural processes", the figure of the refugee comes into being through discursive practice. In the context of Palestinian refugees, Julie Peteet argues that their formation comes into being through two interrelated processes: "violent displacement and denativiazation" (Peteet 2005, 50). The visual and legal field of humanitarianism through which the figure of the refugee discursively emerges, is already organized upon a set of racial orders that find renewal through the circulation of sentimental stories of suffering and benevolence. Such racial stories indeed reconstitute a larger narrative about whiteness and white supremacy under liberal settler colonial orders. Yet, in thinking about humanitarianism as a system of thought and practice that emerges alongside a genealogy of the modern project of race, what do we come to learn about its inflections on the question of Palestine and the political project of return at this historical moment? Put another way, what bearing does this genealogy of liberal humanitarianism have in the context of Palestine, whereby we see a more contentious meeting point between settler colonialism and humanitarian governance?

The tension as I see it here and as this paper has tried to illustrate, is one between two distinct but interrelated projects (return and humanitarianism), both of which are forced to contend with the modern project of race. The very terms through which the United Nations could remedy this historical catastrophe - indeed, in part of their own making - was through a discursive and extra-discursive set of practices that failed to provide redress to Palestinian refugees as Indigenous subjects in a sovereignty struggle over land. What took priority in the immediate aftermath of expulsion was not the return of Palestinians to their land but the distribution of aid and shelter. The provision of humanitarian aid towards a people in a long standing Indigenous sovereignty struggle over land was not a durable solution to expulsion. To be clear, I am not and have not suggested that these two projects (humanitarian assistance and repatriation to land)

\footnotetext{
${ }^{14}$ For instance, in Saidiya Hartman's exploration of dominant representations of terror formation on the slave plantation, she asks us to think carefully about how we encounter slave narratives through thinking about what they do for us and what we need from them. In her words, "What does the exposure of the violated body yield? Proof of black sentience or the inhumanity of the "peculiar institution"? Or does the pain of the other merely provide us with the opportunity for self-reflection? (Hartman 1997, 4). Echoing these methodological cautions concerning the circulation and consumption of suffering and sentimentality, Sherene Razack also reflects on the ways that national subjects are formed through a "peculiar process of consumption" which she identifies as "stealing the pain of others" (Razack 2007). Examining Canadian reactions to humanitarian and media representations of the Rwandan genocide, Razack suggests that the very act of Canadian desires to witness "Rwandan's pain has mostly served to dehumanize them further, and in the process, to reinstall us as morally superior in relation to them" (Razack 2007, 376). Calling into question the slippery relationship between empathy and racism, she asks: "How does it happen? Can it be otherwise? That is, how do we feel their pain and see their humanity? Most of all, how do we recognize our own complicity and move through outrage to responsibility?" (Razack 2007, 376). Examining the specific context of Canada's varied humanitarian responses to the Indigenous suicide crisis in Attawapiskat and the arrival of Syrian refugee communities to Canada, Carmela Murdocca's (2020) work has also illustrated how settler colonial societies rely upon humanitarian logics and "moral vernaculars" to organize settler state building upon and disavow their own racial histories.
} 
cannot and should not happen simultaneously. Today, organizations like UNRWA provide essential services to over five million Palestinian refugees across the Arab world, with support to over a million refugees in Gaza alone, are facing the imminent risk of closure. The results of this would be catastrophic for registered Palestinian refugees in Jordan, Syria, Lebanon as well as inside the West Bank and particularly Gaza which, due to continuous Israeli military bombardment, its debilitated economy emerging from the thirteen-year siege, infrastructural violence, and isolation policies imposed by leading Israeli architects and demographers, has already been deemed unliveable by the year 2020 (UNSCO Official Records A/364, 2017). Additionally, this closure would serve the broader ideological goals between the Israeli government and Trump administration as we've seen mapped out in the so called 'Middle East Peace Plan'. Further, recent cuts in humanitarian funding structures such as in the case with UNRWA have not only had devastating material consequences but at a symbolic level, these strategies work to delimit the very category of Palestinian refugees by deciding who is and is not a refugee, which the Israeli Ministry of Foreign Affairs has aggressively attempted to establish through sustained PR campaigns against UNRWA (Kelcey and Irfan 2019). This would no doubt have direct implications for future peace negotiations and/or reparation packages. What I am suggesting however is that humanitarianism in general and as practiced under settler colonial life in this specific context gives rise to a convergence between racialized modalities of governance. In the West Bank, Gaza and East Jerusalem, the biopolitical nature of humanitarian agencies that determine the very calculus of life placed on Palestinian refugees is met alongside a relentless necropolitical settler state policy predicated on the politics of elimination and enacted through ongoing processes of dispossession, land confiscation, and subjugation. This meeting point between settler colonial and humanitarian governance institutes a particular kind of racial regime that further forecloses the space for which claims to return can hold resonance.

\section{Conclusion}

Had the events surrounding redress for Palestinians centered return in the early years of expulsion, what might the question of Palestine look like today? Perhaps the question might seize to exist. Perhaps not. As the introduction of this essay suggests, return is not bound or constrained by rights discourse or political membership within the nationstate. On the contrary, as extraterritorial subjects and/or second-class citizens, Palestinian refugees are historical subjects formed against the modern-state. In this prolonged state of expulsion and wait, displaced Palestinians have persistently found alternative grammars to articulate their claims to return, a claim that haunts the impermanence of the settler state today. Against this context, it seems important to remember that the context of Palestinian refugees was not always framed as a humanitarian one. Rather, we can trace the historical moments and events that gave rise to this discursive shift at the level of international recognition. When we look closely at the discursive and extra-discursive events that give rise to this shift, there lives another archive that reveals the struggle of a native population from Palestine seeking to return to Palestine. As evidenced in the progress reports by Bernadotte, we see that as the newly declared state of Israel entrenched their claims to sovereignty under international law, Palestinians were slowly but steadily made into subjects of humanitarian governance 
and regarded as refugees, indeed invoking an imaginary of a people not of the land. By depositing a land based reparative justice question into a protracted humanitarian solution, international humanitarian interventions have refashioned how Palestinians come to be represented within a global imaginary. And yet, we would be remised to ignore how Palestinian refugees and the camp continue to represent a radical site of embodied refusal against the racialized structure of humanitarianism and a settler colonial project very much incomplete. It is here, in the place of refusal that we are called into another representation all together, whereby displaced Indigenous Palestinian refugees are both the outcasted subject of settler colonial nation building and its greatest threat. Within this imaginary, enunciations of return need not only be heard as an unimplemented reparative justice principle waiting to be actualized but a radical claim to the human outside of the modern state and all that it promises. Surely, the creative life worlds through which claims to Palestinian return echo through and find renewal in, are a signpost for something already here.

\section{References}

Abdo, N., and Masalha, N., eds., 2018. An Oral History of the Palestinian Nakba. University of Chicago Press.

Abourahme, N., 2011. Spatial Collisions and Discordant Temporalities: Everyday Life between Camp and Checkpoint. International Journal of Urban and Regional Research [online], 35(2), 453-461. Available from: https://doi.org/10.1111/j.14682427.2010.01034.x [Accessed 7 May 2020].

Abu El Haj, N., 2010. Racial palestinianization and the Janus-faced nature of the Israeli state. Patterns of Prejudice [online], 44(1), 27-41. Available from: https://doi.org/10.1080/00313220903507610 [Accessed 7 May 2020].

Al Jazeera, 2014. Killing the Count. Al Jazeera Special Series [online], 13 June.

Documentary. Available from:

http://www.aljazeera.com/programmes/specialseries/2014/06/killing-count20146282143931887.html [Accessed 7 May 2020].

Al-Khalidi, W., ed., 1992. All That Remains: The Palestinian Villages Occupied and Depopulated by Israel in 1948. Washington, DC: Institute for Palestine Studies.

Allan, D., 2014. Refugees of the Revolution: Palestinian Experiences of Exile. Palo Alto: Stanford University Press.

Asad, T., 2015. Reflections on Violence, Law, and Humanitarianism. Critical Inquiry [online], 41(2), 390-427. Available from: https://doi.org/10.1086/679081 [Accessed 7 May 2020].

Badil Resource Center for Palestinian Residency and Refugee Rights, 2011. Q \& A: What you need to know about Palestinian Refugees and Internally Displaced Persons [online]. May. Bethlehem: Badil Resource Center for Palestinian Residency and Refugee Rights. Available from: http://www.badil.org/phocadownloadpap/Badil_docs/publications/Q\&A-en.pdf [Accessed 7 May 2020]. 
Barakat, R., 2017. Writing/right Palestine studies: settler colonialism, indigenous sovereignty and resisting the ghost(s) of history. Settler Colonial Studies [online], 8(3), 349-363. Available from: https://doi.org/10.1080/2201473X.2017.1300048 [Accessed 7 May 2020].

Bhandar, B., 2018. Colonial Lives of Property: Law, Land, and Racial Regimes of Ownership. Durham: Duke University Press.

Campt, T., 2017. Listening to Images. London: Duke University Press.

Collins, J., 2004. Occupied by Memories: The Intifada Generations and the Palestinian State of Emergency. New York University Press.

Corbin, J., 2017. The Balfour Declaration: My ancestor's hand in history. BBC News [online], 31 October. Available from: http://www.bbc.com/news/world-middleeast-41763648 [Accessed 7 May 2020].

Coulthard, G., 2014. Red Skin, White Masks: Rejecting the Colonial Politics of Recognition. Minneapolis: University of Minnesota Press.

Erakat, N., 2019. Justice for Some: Law and the Question of Palestine. Redwood City: Stanford University Press.

Fahoum, R., 2019. Ethnographies of Palestinian Futures. Vancouver: Insaniyyat, Society of Palestinian Anthropologists/American Anthropological Association.

Fanon, F., 1952. Black Skin, White Masks. New York: Grove Press.

Fassin, D., 2007. Humanitarianism as a Politics of Life. Public Culture [online], 19(3), 499-520. Available from: https://doi.org/10.1215/08992363-2007-007 [Accessed 7 May 2020].

Fassin, D., 2012. Humanitarian Reason: A Moral History of the Present. Trans.: R. Gomme. Berkeley: University of California Press.

Feldman, I., 2012. The Humanitarian Condition: Palestinian Refugees and the Politics of Living. Humanity [online], 3(2), 155-172. Available from: https://doi.org/10.1353/hum.2012.0017 [Accessed 7 May 2020].

Feldman, I., 2018. Life Lived in Relief: Humanitarian Predicaments and Palestinian Refugee Politics. Oakland: University of California Press.

Ferreira da Silva, D., 2018. Hacking the Subject: Black Feminism and Refusal beyond the Limits of Critique. philoSOPHIA [online], 8(1), 19-41. Available from: https://doi.org/10.1353/phi.2018.0001 [Accessed 7 May 2020].

Goldberg, D., 2008. Racial “Palestiniazation”. In: R. Lentin, ed., Thinking Palestine. New York: Zed Books, 25-45.

Goldberg, D., 2009. The Threat of Race: Reflections on Racial Neoliberalism. Oxford: Blackwell.

Hartman, S., 1997. Scenes of Subjection: Terror, Slavery, and Self-Making in NineteenthCentury America. New York: Oxford University Press.

Hartman, S., 2018. Refusal and Radical Hope [Discussion, YouTube clip]. Amsterdam: Tropentheatre. RCMC [online], 14 November. Available from: 
https://www.youtube.com/watch?v=XXQqyzTP1zU\&t=5326s [Accessed 7 May 2020].

Ibrahim, I.J., 2012. A Letter from a Palestinian Refugee to a Syrian Refugee (Trans.: M. Alaa). [Blog post]. Gazanism [online], 3 September. Available from:

https://gazanism.wordpress.com/2012/09/03/a-letter-from-a-palestinian-refugeeto-a-syrian-refugee/ [Accessed 7 May 2020] (Original letter dated 1 September 2011).

Irfan, A., 2020. Palestine at the UN: The PLO and UNRWA in the 1970s. Journal of Palestine Studies, 49(2), 26-47.

Kanafani, G., 2000. Returning to Haifa. In: B. Harlow and K. Riley, eds., Palestine's Children: Returning to Haifa and Other Stories. Trans.: K.E. Riley. London: Lynne Rienner.

Kelcey, J., and Irfan, A., 2019. The Importance and Impossibility of Researching UNRWA [Blog post]. Jadaliyya [online], 21 September. Available from: https://www.jadaliyya.com/Details/40008/The-Importance-and-Impossibility-ofResearching-UNRWA [Accessed 7 May 2020]

Khalidi, R., 1992. Observations on the Right of Return. Journal of Palestine Studies [online], 21(2), 29-40. https://doi.org/10.1525/jps.1992.21.2.00p00876 [Accessed 7 May 2020].

Khalidi, R., 2017. The Balfour Declaration from the Perspective of the Palestinian People [online]. Lecture. 2 November. New York: United Nations. Available from: https://www.un.org/unispal/wp-content/uploads/2017/10/Lecture-by-Prof.Rashid-Khalidi-100-years-since-Balfour-Decl-UN-2Nov2017.pdf [Accessed 7 May 2020].

Khalidi, R., 2020. The Hundred Years' War on Palestine: A History of Settler Colonialism and Resistance, 1917-2017. New York: Metropolitan Books.

Makdisi, S., 2010. The Architecture of Erasure. Critical Inquiry [online], 36(3), 519-559. Available from: https://doi.org/10.1086/653411 [Accessed 7 May 2020].

Malkki, L., 1996. Speechless Emissaries: Refugees, Humanitarianism, and Dehistoricization," Cultural Anthropology [online], 11(3), 377-404. Available from: https://doi.org/10.1525/can.1996.11.3.02a00050 [Accessed 7 May 2020].

Masalha, N., 1992. Expulsion of the Palestinians: The Concept of 'Transfer' in Zionist Political Thought, 1882-1948. Washington, DC: Institute for Palestine Studies.

Massad, J., 2006. The Persistence of the Palestinian Question: Essays on Zionism and the Palestinians. New York: Routledge.

Mbembe, A., 2003. Necropolitics. Public Culture [online], 15(1), 11-40. Available from: https://doi.org/10.1215/08992363-15-1-11 [Accessed 7 May 2020].

Murdocca, C., 2013. To Right Historical Wrongs: Race, Gender and Sentencing in Canada. Vancouver: UBC Press.

Murdocca, C., 2020. "Let's help our own": Humanitarian compassion as racial governance in settler colonialism. Oñati Socio-Legal Series [online], 10(6-this issue). 
Available from: https://doi.org/10.35295/osls.iisl/0000-0000-0000-1067 [Accessed 7 May 2020].

Osipenko, N.A., 2016. Two Plans of Folke Bernadotte - First Attempts to Search for Peace. International Journal of Social Science and Humanities [online], 6(9). Available from: https://doi.org/10.7763/IJSSH.2016.V6.698-705 [Accessed 7 May 2020].

Pappe, I., 2006. The Ethnic Cleansing of Palestine. Oxford: One World.

Peteet, J., 2005. Landscape of Hope and Despair: Palestinian Refugee Camps. Philadelphia: University of Pennsylvania Press.

Rajaram, P.K., 2002. Humanitarianism and Representations of the Refugee. Journal of Refugee Studies [online], 15(3), 247-264. Available from: https://doi.org/10.1093/jrs/15.3.247 [Accessed 7 May 2020].

Razack, S.H., 2007. Stealing the Pain of Others: Reflections on Canadian Humanitarian Responses. Review of Education, Pedagogy, and Cultural Studies [online], 29(4), 375394. Available from: https://doi.org/10.1080/10714410701454198 [Accessed 7 May 2020].

Richter-Devroe, S., 2013. “Like Something Sacred": Palestinian Refugees' Narratives on the Right of Return. Refugee Survey Quarterly [online], 32(2), 92-15. Available from: https://doi.org/10.1093/rsq/hdt002 [Accessed 7 May 2020].

Robinson, S., 2013. Citizen Strangers: Palestinians and the Birth of Israel's Liberal Settler State. Redwood City: Stanford University Press.

Sa'di, A.H., and Abu-Lughod, L., eds., 2007. Nakba: Palestine, 1948 and the Claims to Memory. New York: Columbia University Press.

Said, E. (with J. Mohr, photographs), 1986. After the Last Sky: Palestinian Lives. New York: Columbia University Press.

Said, E., 1979. Zionism from the Standpoint of its Victims. Social Text [online], no 1 , (Winter), 7-58. Available from: https://doi.org/10.2307/466405 [Accessed 7 May 2020].

Salih, R., 2016. Bodies that walk, bodies that talk, bodies that love, Palestinian women refugees, affectivity and the politics of the ordinary. Antipode: A Radical Journal of Geography [online], 49(3), 742-760. Available from:

https://doi.org/10.1111/anti.12299 [Accessed 7 May 2020].

Sansour, L., 2016. In the Future, They Ate from the Finest Porcelain. Film. Directed by S. Lind and L. Sansour. UK/Denmark/Qatar: Spike Film and Video.

Sayigh, R., 1979. Palestinians: From Peasants to Revolutionaries: A People's History. London: Zed Books.

Seikaly, S., 2015. Men of Capital: Scarcity and Economy in Mandate Palestine. Redwood City: Stanford University Press.

Shafir, G., 1989. Land, Labor and the Origins of the Israeli-Palestinian Conflict, 1882-1914. New York: Cambridge University Press. 
Shalhoub-Kevorkian, N., 2015a. Necropolitical Debris: The Dichotomy of Life and Death. State Crime Journal [online], 4(1), 34-51. Available from: https://doi.org/10.13169/statecrime.4.1.0034 [Accessed 7 May 2020].

Shalhoub-Kevorkian, N., 2015b. Security Theology, Surveillance and the Politics of Fear [online]. Cambridge University Press. Available from: https://doi.org/10.1017/CBO9781316159927 [Accessed 7 May 2020].

Shalhoub-Kevorkian, N., 2016. Infiltrated Intimacies: The Case of Palestinian Returnees. Feminist Studies [online], 42(1-Everyday Militarism), 166-193. Available from: https://doi.org/10.15767/feministstudies.42.1.166 [Accessed 7 May 2020].

Simpson, A., 2014. Mohawk Interruptus: Political Life Across the Borders of Settler States. Durham: Duke University Press.

Stranger, C.D., 1988. A Haunting Legacy: The Assassination of Count Bernadotte. The Middle East Journal, 42(2), 260-272.

Tabar, L., 2016. Disrupting Development, Reclaiming Solidarity: The Anti-Politics of Humanitarianism. Journal of Palestine Studies, 45(4), 16-31.

The Funambulist, 2014. Sophia Azeb, The "No-State Solution". The Funambulist [online], 27 April. Podcast. Available from: https://thefunambulist.net/podcast/sophia-azeb-the-no-state-solution-power-ofimagination-for-the-palestinian-struggle [Accessed 7 May 2020].

Vadasaria, S., 2015. Necronationalism: Managing race, death and the nation's skeletons. Social Identities: Journal for the Study of Race, Nation and Culture [online], 21(2), 117-131. Available from: https://doi.org/10.1080/13504630.2015.1041014 [Accessed 7 May 2020].

Vadasaria, S., 2018. Temporalities of "Return": Race, Representation and Decolonial Imaginings of Palestinian Refugee Life. Ph.D. Dissertation. Toronto: York University.

\section{Official Documents}

Appointment and terms of reference of a United Nations Mediator in Palestine (A/RES/186 (S2)) [online]. UN General Assembly, 14 May 1948. Available from: https://unispal.un.org/DPA/DPR/unispal.nsf/0/A9A8DA193BD46C54852560E5006 0C6FD [Accessed 7 May 2020].

Official Records of the Second Session of the General Assembly, Supplement nำ11, A/364 [online]. Lake Success: United Nations Special Committee on Palestine, 3 September 1947. Available from:

https://unispal.un.org/DPA/DPR/unispal.nsf/0/07175DE9FA2DE563852568D3006 E10F3 [Accessed 1 August 2017].

Progress Report of the United Nations Mediator on Palestine Submitted to the SecretaryGeneral for the Transmission to the Members of the United Nations (Third Session, Supplement no 11, A/648) [online]. Paris: UN General Assembly. 16 September 1948. Available from: 
https://unispal.un.org/UNISPAL.NSF/0/AB14D4AAFC4E1BB985256204004F55FA [Accessed 1 August 2017].

Text of Suggestions Presented by the United Nations Mediator on Palestine to the Two Parties (S/863) [online]. New York: United Nations, 28 June 1948. Available from: https://digitallibrary.un.org/record/470499 [Accessed 1 August 2017].

United Nations Country Team in the occupied Palestinian Territory, 2017. Gaza Ten Years Later [online]. July. Available from:

https://unsco.unmissions.org/sites/default/files/gaza_10_years later_11 july 2017.pdf [Accessed 7 May 2020].

United Nations General Assembly Resolution 181 (III), Future Government of Palestine (A/RES 181 (II)) [online]. UN General Assembly, 29 November 1947. Available from:

https://unispal.un.org/DPA/DPR/unispal.nsf/0/7F0AF2BD897689B785256C330061

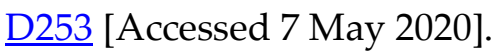

United Nations Office for the Coordination of Humanitarian Affairs, 2019.

Humanitarian Coordinator for the occupied Palestinian territory, Mr. Jamie McGoldrick, calls for action to prevent further loss of life and injury in the Gaza Strip [online]. 29 March. Available from: https://www.ochaopt.org/content/humanitariancoordinator-occupied-palestinian-territory-mr-jamie-mcgoldrick-calls-action [Accessed 7 May 2020]. 